\title{
The analytical assessment of the weaknesses of the agriculture of Szabolcs-Szatmár-Bereg County based on empirical research results
}

\author{
István TAKÁCS, ${ }^{1}$ Adrien FENYVESI, ${ }^{2}$ Botond SINÓROS-SZABÓ ${ }^{3}$ \\ ${ }^{1}$ University of Debrecen, Kálmán Kerpely Doctoral School, Debrecen, Hungary, \\ e-mail: taktamist@gmail.com \\ ${ }^{2}$ Lilleby Skole, Trondheim, Norway; e-mail: fenyvesi.adrien@gmail.com \\ ${ }^{3}$ University of Debrecen, Faculty of Agricultural and Food Sciences \\ and Environmental Management, Debrecen, Hungary
}

03 September 2020; revised: 01 October 2020; accepted: 14 November 2020

\begin{abstract}
In our empirical research, we examined the agriculture of SzabolcsSzatmár-Bereg County. We surveyed the situation of agriculture through farmers using certain criteria to rank the situation within the framework of a SWOT analysis. The responses received from farmers in the county were quantified and evaluated on the basis of what these farmers have considered to be true. The interdisciplinary study of agriculture is a timely and important task. It can be enforced on the basis of systemic contexts studying not only food production but also environmental issues, preservation of rural habitats, employment, and regional development.
\end{abstract}

Keywords: system approach, situation assessment, interdisciplinary study, agriculture, regionalism

\section{Introduction}

Agriculture, as a product-producing and value-creating activity, plays a special but increasingly diminishing role in the structure of the Hungarian economy and thus in its overall performance. Based on its fundamental potential, it influences its processes and trends and defines both food production and environmental protection.

In this systematic approach, the most important question, if not the only one, of agriculture and humanity is our ability to preserve ecological and economic diversity, the natural quantity and diversity of our natural resources, and the 
richness of the flora and fauna [1]. In an environment under increasing pressure, such as a resource crisis, population explosion, ensuring healthy food production, energy demand, a proper way of life, and job security in rural areas, the technological and technical advances of agriculture are the basis of population growth [2]. The population growth rate has slowed down recently, but given the anticipated figures, new systemic solutions must be found to ensure sufficient water, food, and energy supply, while all solutions must be based on environmental protection and preserving biodiversity [3].

The utilized agricultural area of Hungary has decreased due to urbanization, land use due to the development of various elements of the infrastructure, and the transformed economy and ownership structure. As a result, during the last half a century, Hungary has lost almost 1.6 million hectares of agricultural land. Compared to the total area of Hungary, this represents $17.2 \%$, and compared to all areas used for agriculture in Hungary this amounts to $28 \%$. This decrease can be observed in the Northern Plains and Szabolcs-Szatmár-Bereg County as well. Despite the decreasing agricultural land, more and more food is needed for the growing population. In the crop structure configuration, farmers need to consider both external and internal factors as well as they need to determine their current situation and their goals to be achieved. The rapidly changing economic and natural environment, technological knowledge transfer and demographic change call into question many permanent economic and social paradigms [4].

According to the SWOT framework, the factors can be grouped into four categories to provide a basis for achieving specific goals. The analysis uses the method of strategic evaluation. We considered it necessary to consult the farmers participating in the survey on this issue. Taking account of the four criteria, through their own businesses, their advantages and disadvantages over their competitors are revealed. Within the external environment, opportunities are positive, and threats have a negative impact on the business [5]. SWOT analysis helps analyse the situation of businesses. We can identify Strengths, Weaknesses, Opportunities, and Threats. The development of the method can be linked to Stanford University. When classifying the criteria, we asked the farmers themselves to decide, to the best of their ability, which of the external and internal features of their agricultural enterprise were to be classified as weaknesses. The following attributes had the greatest proportion: land prices and land rents, changes in the selling price of cereals, available processing capacity, available irrigation capacity, changes in production costs, producer sales, animal nutrition and animal husbandry, and producer association and cooperation. These are all negative signs of the county. These factors are judged either to be negative or to have an inadequate degree or even none.

The environmental impact of agriculture is the most significant human activity [6]. The characteristic feature of Hungarian agriculture is that it is the 
most significant natural resource available based on its abilities and capabilities. It is determined by the totality of such conditions and system approach [7]. Agriculture, as a product-producing and value-creating activity, plays a special but increasingly diminishing role in the structure of the Hungarian economy and thus in its overall performance. Agriculture and regional development can be examined in a system approach $[8,9]$. Factors considered as traditional strengths need to be continually examined, most notably climate, as environmental changes have a significant impact on food production volumes and safe production and supply.

Climate change affects rainfall and the amount of irrigation water available, the species and quantity of plant and animal pests and has a major influence on the yield of the most important agricultural measurement factor [10]. Economy and production plans are rendered nearly impossible by temperature fluctuations and the increasing occurrence of unplanned extreme events [11, 12]. This is confirmed by the observation that annual rainfall has decreased from 640 millimetres to 560 millimetres, and its distribution over time is unpredictable [13, 14]. The type of irrigation is primarily determined by the soil, the temporal and spatial distribution of the hydrological water shortage, the cultivation technology, the asset and workforce potential of business organizations, and the quality and quantity of surface water or groundwater available $[15,16]$. They form the same body of water [17]. Water management has become a key domestic and global strategic issue, now more important than ever in human history [18].

Mapping, evaluating, and correctly interpreting competitive advantages at the level of individual and national economies is one of the most important tasks of agricultural policy. This is the basis of commercial success [19]. The structure of the formulation and implementation of the agricultural strategy must change. Instead of traditional thinking, faster and more flexible forms should be preferred. Mostly strategies based on improvisation, action plans, and visions are viable. They can keep up with the rapidly changing market situation [20]. There is an important fundamental interest in competitiveness that favours the introduction of strategies that search for the direction and application of sustainable development in the field of environment and nature [21, 22, 23].

Most of Szabolcs-Szatmár-Bereg County, which provided the framework for the study, is lagging behind $[24,25]$, is a peripheral area $[26,27,28]$ missing an economic and social centre [29, 30]. Our research, however, is a niche, one that offers novel insights into a previously less researched topic. Our empirical results can also contribute to the preparation of a larger (nationally representative) research. 


\section{Materials and methods}

In our paper, we examined the agriculture of Szabolcs-Szatmár-Bereg County through the opinions and experiences of farmers. Research has been carried out among maize and winter wheat cultivation organizations as these are the two most important terrestrial cereals. The basic population of the survey is the agricultural entrepreneurial world of the county, data on which was obtained through sixty agricultural advisers of the National Chamber of Agriculture in Szabolcs-Szatmár-Bereg County. They were contacted electronically with the help of the NAK County Board, closed-ended questionnaire using Google Forms (CAPI - Computer-Aided Personal Interview). The questionnaire was sent electronically to the agricultural advisers, and responses were also sent back electronically. Correlation coefficient analysis was performed to detect relationships. Farmers were able to answer the questions with a multiple-choice numerical value on a 5-point Likert scale (a measurement scale between two extremes) with 1 - the least and 5 - very textual explanations. It was a good solution to choose five grades for the well-known and well-managed value range because everyone could relate the value of individual grades to the value of school grades. In addition, the SWOT analysis method was used in the questionnaire for the values of the answers to the questions. The focus of the questions was to get to know the farms that produce arable crops.

The agricultural advisers helped to fill out the questionnaire for each farmer. Each farmer who was producing arable crops was randomly selected from the clients of the agricultural adviser (400-450 clients per adviser) in a way that a representative subjective knowledge may be discovered. By this method, we can also discover the objective data linked to crop production. We asked for consensual answers beyond those based on non-quantifiable data. It takes the greatest effort to reach a common decision: time, attention, flexibility; but in this case the data may reflect the views of a larger community. In reaching an agreement, it may be difficult to involve a sufficiently wide range of participants and stakeholders in the decision. This is why the knowledge of agricultural advisers is important. Thus, the data are based on a convincingly large number of databases. The knowledge of agricultural advisers is extensive and unmatched $(8,000$ clients per year). Due to the occurrence of randomness, the research is considered representative.

The research was conducted between 12 December 2018 and 12 September 2019. Sampler: 60 agricultural advisers. Sample size: 8,000 persons.

Sampling: the questionnaire was sent to all agricultural advisers with a return rate of $98.3 \%$, i.e. $59 / 60$. We used the following methods to increase the level of response we receive: motivational letter of invitation through the board, telephone, and personal questions and answers. The results can be generalized to 
the whole county because this sampling group is responsible for liaison, information transfer, and any assistance related to their farming activities. Filling in the questionnaires can be affected by the following factors: Internet access (it was provided by agricultural advisers), interest, and commitment to the topic. These factors are taken into account when interpreting our results. During data processing and compression, I used simple and weighted arithmetic mean calculations as well as distribution ratio calculations. The closeness of the relationship between the quality criteria was examined by cross-table analysis and calculated by Tschuprow's T measure of association.

\section{Results and discussions}

The figures in the study show the data and ratings of the participants as well as their views on a particular issue. From the data in the tables, which show the results of the whole research, in this publication we evaluate the answers based on the results of the SWOT analysis and reveal possible correlations. The tables display percentages.

Participants included almost four times as many men (47 persons, 80\%) as women (12 persons, 20\%). The county's agriculture as a whole is typically dominated by men.

By age distribution: 11 persons (19\%) below 40 years of age and 48 persons (81\%) above 40 years of age. The average age of participants is 49.06 years of age. Average deviation of farmers' age from the average -24 and +16 years.

The respondents were divided into four groups according to their education. Higher education: 10 persons (17\%), secondary education: 39 persons $(66 \%)$, primary education: 7 persons (12\%), and no formal education: 3 persons (5\%). In terms of formal agricultural education: 53 persons $(90 \%)$ have some sort of formal education, and 6 persons $(10 \%)$ do not have formal agricultural education.

There are 13 districts in Szabolcs-Szatmár-Bereg County. We have received data from 9 districts. Figure 1 shows the percentage of participants from the different districts. The largest number of participants is from the Nyíregyháza district with 13 persons. This district has the largest population within the county as well as the county seat. The second largest samples came from the Nagykálló district. This is located right next to Nyíregyháza (10 persons). The third and fourth largest providers of participants were Csenger $(8$ persons $)$ and Fehérgyarmat (7 persons). These two districts are located at the east side of the county. Szabolcs-Szatmár-Bereg County is a special agricultural county: the weight of agriculture is more than twice the national average $[2,20]$. 


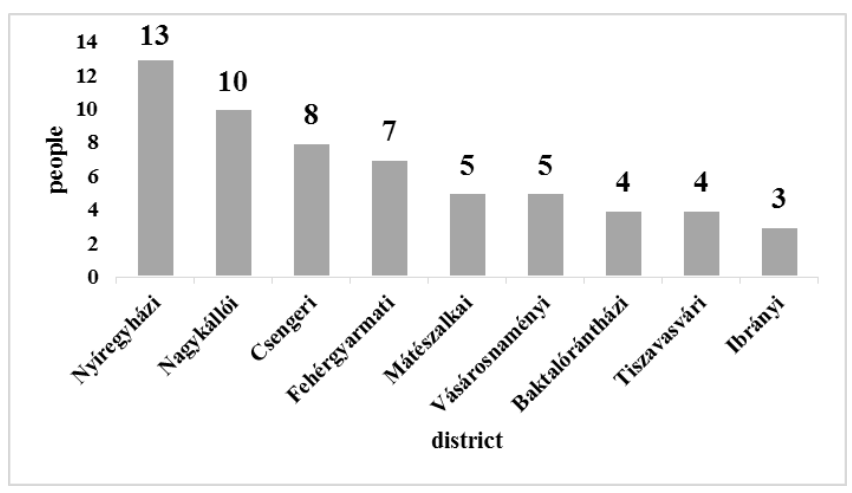

Figure 1. The geographical location of farmers, by districts

The size of arable land is given by the participants (Figure 2). The area of the farmers ranges from 1 to 470 ha. They farm an average of 40.16 ha, the standard deviation of the area being $72.7 \mathrm{ha}$. Self-owned arable lands range from 0 to 380 ha, of which on average 31.48 ha are privately owned, with a standard deviation of 57.6 ha. The area under other cultivation is between 0 and 200 ha, with an average of 9.07 ha and with a standard deviation of 28.3 ha. The largest area is the Tiszavasvári (700 ha) and the smallest is the Baktalórántházi district (42.12 ha).

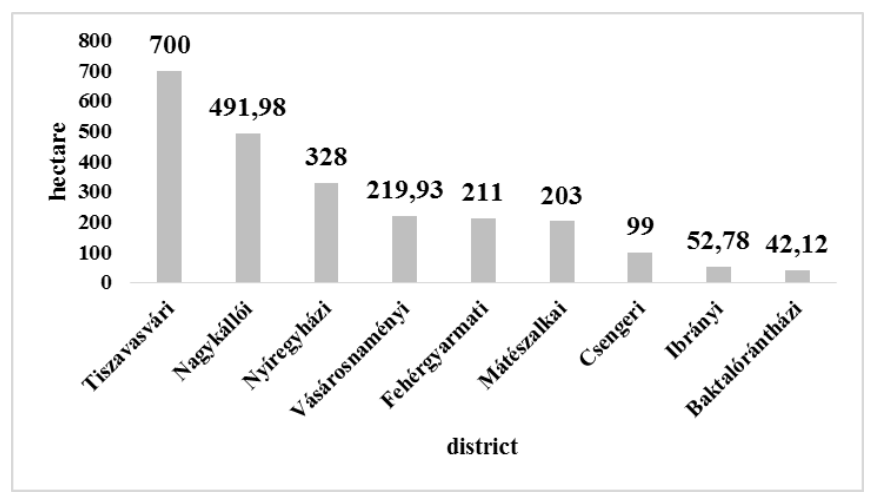

Figure 2. Size and district of farmers' arable lands

The arable area given by the survey participants is the typical Golden Crown (GC) in the particular districts. The average Golden Crown value of the participating farmers is $16.24 \mathrm{GC}$. The best value is in the Tiszavasvári area (Figure 3). There is a significant difference between the districts in this value between the cultivated fields. The average Golden Crown value of the agricultural 
areas of the region is 16.26 GC. Szabolcs-Szatmár is around 12.31 GC in Bereg County, 17.08 GC in Hajdú Bihar, and 19.41 GC in Jász-Nagykun-Szolnok County. The country average is 18,15 GC [31].

The typical Golden Crown value of arable land given by the survey participants ranges from 4 to $29 \mathrm{GC}$ in each district. The average Golden Crown value for farms is $16.24 \mathrm{GC}$, its standard deviation being $5.2 \mathrm{GC}$. The typical Golden Crown value of arable land given by the survey participants ranges from 4 to $29 \mathrm{GC}$ in each district. The average Golden Crown value for farms is 16.24 GC, its standard deviation being 5.2 GC. The Tiszavasvári area has the best average value, while the Baktalórántházi has the worst. The average Golden Crown value of the farms is above the county's average by $3.93 \mathrm{GC}$. It is almost at the regional level, just below by $0.02 \mathrm{GC}$. The average GC value of the farms participating in the survey is significantly worse than the average of JászNagykun-Szolnok County by -3.17 GC. This is below the average value of HajdúBihar County by -0.84 GC.

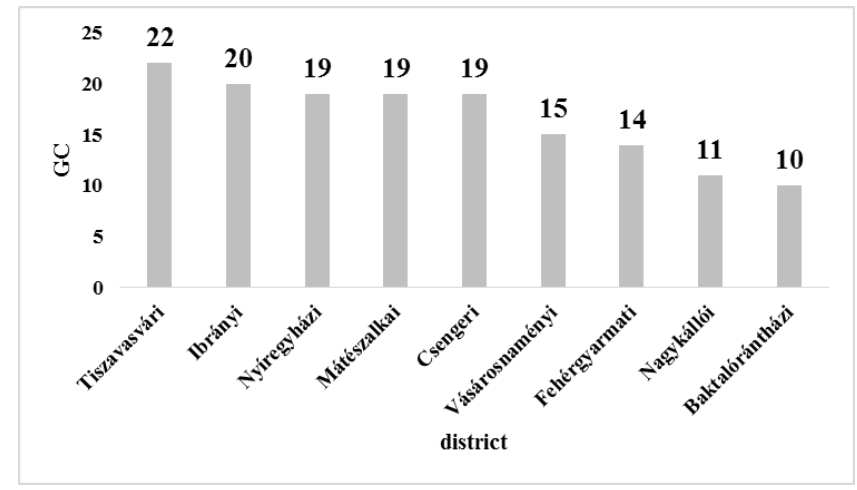

Figure 3. Average Golden Crown value per farmer per district

With the help of the SWOT analysis, we assessed the external and internal environment of the county's agriculture and identified the specific weaknesses in the presence of which farmers should produce. The SWOT analysis by county farmers is based on Strength, Weaknesses, Opportunities, and Threats acronyms (Table 1).

County farmers do not regard the weather and natural conditions of the county as weaknesses. However, it is a significant discovery that the factors of production attributed to weakness point out both abilities and skills. Based on this, it can be said that in a good natural environment (external environment) agriculture with low potential (internal environment) is conducted in the county. The close values of the opportunity, with the exception of land prices and 
production costs, show that farmers see some room for improvement in this respect. The results on production costs highlight that farmers pay less attention to cost administration and record keeping when they plan their budget.

Table 1. "Weaknesses" of county agriculture

\begin{tabular}{|l|c|c|c|c|}
\hline \multicolumn{1}{|c|}{ Factors/Characteristics } & $\begin{array}{c}\text { Strengths } \\
(\mathbf{\%})\end{array}$ & $\begin{array}{c}\text { Weaknesses } \\
(\mathbf{\%})\end{array}$ & $\begin{array}{c}\text { Opportunities } \\
(\mathbf{\%})\end{array}$ & $\begin{array}{c}\text { Threats } \\
(\mathbf{\%})\end{array}$ \\
\hline Land prices and land rents & 1.7 & 54.2 & 25.4 & 18.6 \\
\hline $\begin{array}{l}\text { Changes in the selling price of } \\
\text { cereals }\end{array}$ & 5.1 & 54.2 & 23.7 & 16.9 \\
\hline Available processing capacity & 6.8 & 47.5 & 42.4 & 3.4 \\
\hline Available irrigation capacity & 5.1 & 50.8 & 40.7 & 3.4 \\
\hline Changes in production costs & 5.1 & 35.6 & 23.7 & 35.6 \\
\hline Producer sales & 6.8 & 44.1 & 40.7 & 8.5 \\
\hline $\begin{array}{l}\text { Producer association and } \\
\text { cooperation }\end{array}$ & 3.4 & 47.5 & 47.5 & 1.7 \\
\hline $\begin{array}{l}\text { Animal nutrition and animal } \\
\text { husbandry }\end{array}$ & 11.9 & 42.4 & 42.4 & 3.4 \\
\hline
\end{tabular}

When formulating typical questions, we were guided by the principle of being able to form a broad view of the area in which they should perform their task. We provided an opportunity to evaluate both agricultural activities that can be interpreted closely, and by examining the complex economic, sociological, agricultural, legal, and environmental spheres of their enterprise, from a systemic point of view, we can get answers about their own interpretation and evaluation aspects. When evaluating Producer Association, we can see that they are not taking advantage of the cost-cutting and revenue-raising effects of joint purchasing and selling. This is reassured by listing Producer Sales as a weakness. Considering the fact that Producer Association is a weak and an opportunity factor in the county, it is understandable that Producer Sales is weak, and it is vulnerable to the processing industry. Examining this item along with the purchase price, it shows that they cannot negotiate a good price from the processing companies. Selling to end users directly is very rare. The vulnerability of county farmers is high due to the production of raw materials.

Factors broken down by districts and tabulated according to the four categories show that there is a difference in the opinion of farmers by geographical location. Most of the points in the assessment of weaknesses came from the Nagykálló district. According to the results, this district experiences the weaknesses of the county's agriculture the most (Table 2).

The role of common interest groups and co-operation is not nearly as significant as we would expect it to be, given its importance. Farmers in the Csenger district feel it is one of the biggest issues. They do not want or are not 
able to make use of the opportunity of joint action to sell at better prices and conditions. The task of common interest groups is to assist their members in purchasing and selling. The agriculture of the county is characterized almost every year by an old problem, which is related to the sale. The processing industry puts farmers in a difficult position. The processing capacity was also labelled as a weakness by the farmers, mainly by the farmers of Nagykálló district. Market production of goods is by no means an advocacy task, and it is not a political question. There is a need to negotiate jointly on sales, processing, and purchasing. An adequate financing is also easier to achieve if the sale is resolved.

Table 2. Result of the SWOT analysis, broken down by districts: weaknesses

\begin{tabular}{|c|c|c|c|c|c|c|c|c|c|c|}
\hline Factors/Characteristics & 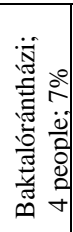 & $\ddot{g}$ & 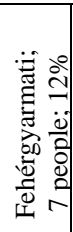 & 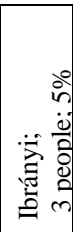 & 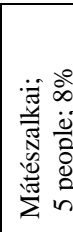 & 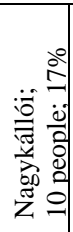 & 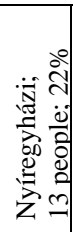 & 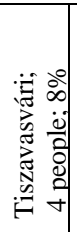 & 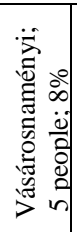 & 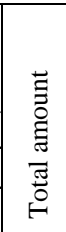 \\
\hline Producer sales & 0 & 4 & 3 & 3 & 3 & 6 & 2 & 2 & 3 & 26 \\
\hline Available processing capacity & 0 & 4 & 4 & 3 & 3 & 8 & 3 & 1 & 2 & 28 \\
\hline Land prices and rents & 2 & 7 & 3 & 2 & 3 & 7 & 4 & 2 & 2 & 32 \\
\hline Change in production costs & 0 & 5 & 2 & 1 & 1 & 3 & 4 & 3 & 2 & 21 \\
\hline $\begin{array}{l}\text { Producer association and } \\
\text { cooperation }\end{array}$ & 0 & 6 & 5 & 3 & 3 & 3 & 3 & 2 & 3 & 28 \\
\hline $\begin{array}{l}\text { Changes in the selling price of } \\
\text { cereals }\end{array}$ & 0 & 6 & 5 & 3 & 4 & 5 & 3 & 3 & 3 & 32 \\
\hline Available irrigation capacity & 0 & 5 & 5 & 2 & 3 & 7 & 4 & 3 & 1 & 30 \\
\hline $\begin{array}{l}\text { Degree of animal feeding and } \\
\text { animal husbandry }\end{array}$ & 0 & 1 & 4 & 3 & 2 & 4 & 7 & 2 & 2 & 25 \\
\hline
\end{tabular}

According to the association results of the SWOT analysis, the most important is the geographical location in the feature-to-factor relationship. The second factor that influenced responses was the age of respondents. Respondents' gender was the third factor in this division, where we could establish a certain relationship. There was a significant relationship between respondents' age and the livestock status.

We were able to show a weak but clear influence on agricultural education. The highest education level has a weak correlation with the characteristics of the relatives' evaluation (Table 3) [32]. 
Table 3. SWOT analysis, the Value of Association Coefficients (T) (where "T" indicates the closeness of the relationship between the factor and the answers to the scientific questions)

\begin{tabular}{|l|c|c|c|c|c|}
\hline \multicolumn{1}{|c|}{ Factors/Characteristics } & Age & Gender & Education & $\begin{array}{c}\text { Agricultural } \\
\text { education }\end{array}$ & District \\
\hline Land prices and land rents & 0.076 & 0.233 & 0.142 & 0.119 & 0.191 \\
\hline $\begin{array}{l}\text { Changes in the selling price of } \\
\text { cereals }\end{array}$ & 0.096 & 0.116 & 0.106 & 0.137 & 0.224 \\
\hline Available processing capacity & 0.160 & 0.199 & 0.167 & 0.214 & 0.304 \\
\hline Available irrigation capacity & 0.226 & 0.059 & 0.178 & 0.243 & 0.224 \\
\hline Changes in production costs & 0.285 & 0.053 & 0.142 & 0.155 & 0.236 \\
\hline Producer sales & 0.169 & 0.259 & 0.164 & 0.176 & 0.249 \\
\hline $\begin{array}{l}\text { Producer association and } \\
\text { cooperation }\end{array}$ & 0.274 & 0.040 & 0.133 & 0.214 & 0.231 \\
\hline $\begin{array}{l}\text { Animal nutrition } \\
\text { and animal husbandry }\end{array}$ & 0.407 & 0.056 & 0.121 & 0.209 & 0.242 \\
\hline
\end{tabular}

\section{Conclusions}

It is characteristic of the results of our investigations that factors classified into the group of weaknesses are traditionally related to sales difficulties. Factors influencing production need to be examined continuously as environmental changes have a significant impact on the volume of food production as well as on safe production and supply. Evaluating and analysing the results of the microregion and the opinions of the farmers provides the statistical values of the larger units. It has always been a difficult task to identify, assess, and take into account the strengths, weaknesses, opportunities, and threats of farming. However, data are needed to analyse the state of the sector: mapping its capabilities, reducing its handicaps, or making use of its competitive advantage. Another challenge that needs to be addressed is that economic calculations take due account of the present and future value of ecology [16, 33]. Planning has already taken into account the organizational strengths and weaknesses, has identified environmental opportunities and threats, and is more likely to achieve goals than in cases where the capabilities of their internal and external environments have not been assessed. In summary, one of the common problems is that the expected difficulties are not calculated during the strategy preparation period, and thus no solutions to mitigate difficulties are developed. 


\section{Acknowledgements}

Publishing of this journal is supported by the Institute for Research Programmes of Sapientia University.

\section{References}

[1] Nagy, J. (2005), A föld az élet és a termelés alapja - ,a föld szeretete a haza szeretete”. In: Fürj, Z., Jávor, A. (eds.), “... a birtokolt föld ... a szabadság maga”. Debrecen: University of Debrecen, ATC. 31-38.

[2] Nagy, J. (2019), Földhasználat. In: Pepó, P. (ed.), Általános növénytermesztési ismeretek. Integrált növénytermesztés I. Budapest: Mezőgazda Lap- és Könyvkiadó. 168-190.

[3] Nagy, J., Sinóros-Szabó, B. (2014), Evaluation of technologies and resources from the spatial and social aspects. In: Jávor, A. (ed.), Agrártudományi Közlemények (Acta Agraria Debreceniensis) 59, 73-75.

[4] Dinya, L. (2018), Változó hangsúlyok a térségfejlesztésben. In: Nagy, J. (ed.), Hangsúlyok a térfejlesztésben. Debrecen. 103-114.

[5] Takács, I. (2010), A történelmi Szatmár Megye gazdasági újraegyesülésének esélyei a határok elválasztó szerepének megszünését követően. In: Szabó, B., Szabó, M., Szele, T. (eds.), VI. Kárpát-Medencei Környezettudományi Konferencia, Nyíregyházi Főiskola. Nyíregyháza. 97.

[6] Takács, I. Sinóros-Szabó, B. (2019), Növényvédelmi költségek csökkentése, kutatási eredményekre alapozva. Rurális Térségek a 21. Században Tudományos Konferencia, Szent István Egyetem, Gödöllö. 222-230.

[7] Csete, L., Láng, I., (2005), A fenntartható agrárgazdaság és vidékfejlesztés. In: Magyarország az ezredfordulón. Stratégiai tanulmányok a Magyar Tudományos Akadémián, II. Az agrárium helyzete és jövője. MTA Társadalomkutató Központ. 313.

[8] Sinóros-Szabó, B. (2004), Technológia és fejlesztés I. Nyíregyházi Főiskola, GTK. Debrecen.

[9] Sinóros-Szabó, B. (2012), Vidéki térrendszer többletei. In: Jávor, A. (ed.), Agrártudományi közlemények (Acta Agraria Debreceniensis) 49, 271-273.

[10] Adams, R. M., Hurd, B. H, Lenhart S., Leary, N. (1998), Effects of global climate change on agriculture: An interpretative review. Climate Research 11, 19-30.

[11] Harnos, Zs., Csete, L. (2008), Klimaváltozás: környezet - kockázat-társadalom. Budapest: Szaktudás Kiadó Ház. 9-14.

[12] Sárvári, M. (2004), Takarmánynövények biológiai alapjainak vizsgálata. In: Integrált agrárgazdasági modellek a XXI. század mezögazdaságában. Debrecen: University of Debrecen, ATC.

[13] Szász, G. (1988), Agrometeorológia. Budapest: Mezőgazdasági Kiadó.

[14] Szász, G. (2013), Agrometerological research and its results in Hungary (1870-2010). Idöjárás/Quarterly Journal of Hungarian Meterological Service 117(3), 315-358.

[15] Neubauer, É. (2014), Vízerőforrás-értékelés vízjáradék-együtthatóval. In: Rajnai, Z., Fregan, B., Ozsváth, J. (eds.), 5. Báthory-Brassai Tanulmánykötet II. Budapest: Óbudai Egyetem, Biztonságtudományi Doktori Iskola. 694-700.

[16] Pretty, J. N., Brett, C., Gee, D., Hine, R. E., Mason, C. F., Morison, J. I. L., Raven, H., Rayment, M. D., van der Bijl, G. (2000), An assessment of the total external costs of UK agriculture. Agricultural Systems 65, 113-136.

[17] Szász, G. (2010), A kukorica vízforgalmát szabályozó tényezők szerepe az öntözésben. In: Nagy, J. (ed.), Az öntözés vállalati szintü elemzése. University of Debrecen, AGC. 32-81. 
[18] Neubauer, É., Bakosné, B. M. (2014), Water Allowance Coefficient as a tool for Hungarian water resource valuation. In: Rajnai, Z., Fregan B., Ozsváth, J. (eds.), 5. Báthory-Brassai Tanulmánykötet II. Budapest: Óbudai Egyetem, Biztonságtudományi Doktori Iskola. 701-708.

[19] Mizik, T. (2019), A három legnagyobb FÁK-ország mezőgazdasági kereskedelmének jellemzői. In: Dusek, T. (ed.), Statisztikai Szemle 97(1), 45-71. Budapest: Központi Statisztikai Hivatal.

[20] Mészáros, T. (2009), Mire építsük stratégiánkat? Miskolci Egyetem, Gazdaságtudományi Kar, VII. Nemzetközi Konferencia, Miskolc-Lillafüred. I: 40.

[21] Baranyi, B., Sinóros-Szabó, B. (2013), A Tisza-tér értelmezésének dilemmái regionális dimenziókban. In: Jávor, A. (ed.), Agrártudományi közlemények. Acta Agraria Debreceniensis 52, 169-171.

[22] Gyuricza, Cs., Kovács, G. P., Balla, I., Bakti, B. (2018), Versenyképes mezőgazdaság a magyar föld jövőjéért - kitörési pontok az agráriumban. In: Nagy, J. (ed.), Hangsúlyok a térfejlesztésben. Debrecen: Kerpely Kálmán Doktori Iskola. 145-156.

[23] Kormos, Z., Harsányi, G. (2018), A hazai zöldség- és gyümölcsfeldolgozás versenyképességének területi vizsgálata az OCRA-módszer segítségével [Spatial analysis of competitiveness of the national vegetable and fruit processing with the help of the OCRA procedure]. In: Tóth, G. (ed.), Területi Statisztika 58(1), 84-102. Budapest: Központi Statisztikai Hivatal.

[24] Nemes-Nagy, J. (1996), Centrumok és perifériák a piac gazdasági átmenetében. Földrajzi Közlemények 2-3, 31-48.

[25] Szücs, J. (1981), Vázlat Európa három történeti régiójáról. In: Történelmi Szemle 81(3), 313-359. Budapest: MTA TIÉ, Akadémiai Kiadó.

[26] Barta, Gy. (1990), Centrum-periféria folyamatok a magyar gazdaság területi fejlödésében? In: Tóth, J. (ed.), Tér-idö-társadalom. Pécs: MTA RKK. 170-188.

[27] Beluczky, P. (1990), „Tradicionális” területi hátrányok és terápiájuk Magyarországon (19481992). In: Tóth, J. (ed.), Tér-idö-társadalom. Pécs: MTA RKK. 49-63.

[28] Beluczky, P. (2002), Területi hátrányok és „kezelésük” Magyarországon 1900-1948-1991. In: Vég kiárusítás II. Társadalomföldrajzi tanulmányok. Pécs: MTA RKK. 71-94.

[29] Thompson, A. A., Strickland, A. J. (1984), Strategic Management - Concepts and Cases. Plano, Texas: Business Publications. 178-179.

[30] Baranyi, B. (2006), A perifériaképződés területi aspektusai Magyarországon. In: Baranyi, B., Nagy, J. (eds.), Területfejlesztés, Agrárium és Regionalitás Magyarországon. MTA RKKUniversity of Debrecen, Agrártudományi Centrum. 33-48.

[31] Marosi, S., Somogyi, S. (1990), Magyarország kistájainak katasztere I-II. Budapest: MTA Földrajztudományi Kutatóintézet. 248-298.

[32] Guilford, J. P. (1956), Fundamental Statistics in Psychology and Education. New York: McGraw-Hill Book Company.

[33] Daily, G. C. (1997), Introduction - What are ecosystem services? In: Daily, G. C. (ed.), Nature's services. Washington, D. C.: Island Press. 1-10.

[34] Nemes-Nagy, J. (1990), Területi egyenlőtlenségek dimenziói. Adalékok egy „kvázielmélethez". Tér és Társadalom 2, 15-30. 